\title{
INVENTARISASI PRAKTIK INOVATIF DALAM PENDIDIKAN UNTUK PEMBANGUNAN BERKELANJUTAN
}

\begin{abstract}
Akhmad Asyari*
Abstrak: artikel ini menyajikan konsep kunci yang mendasari gagasan yang pembangunan berkelanjutan. Pembangunan berkelanjutan, seperti yang didefinisikan oleh Uni Eropa, singkatan memenuhi kebutuhan pembangunan generasi sekarang tanpa membahayakan kemampuan generasi mendatang untuk memenuhi mereka pengembangan sendiri kebutuhan. Pembangunan berkelanjutan tidak hanya berfokus pada lingkungan masalah, tapi secara luas menangkap berbagai dimensi pembangunan. Secara tradisional, pembangunan berkelanjutan secara konseptual dianggap dalam tiga pilar utama: Kelestarian lingkungan, keberlanjutan ekonomi; dan Keberlanjutan sosial.
\end{abstract}

Kata Kunci: Inventarisasi, Inovatif, Pendidikan, Pembangunan Berkelanjutan

trategi Eropa dalam Pembangunan Berkelanjutan mengakui peran penting sistem pendidikan dan pelatihan harus bekerjasama untuk mencapai tujuan yang pembangunan berkelanjutan. Pendidikan dan pelatihan harus memberikan kontribusi untuk pembangunan berkelanjutan melalui dimensi sosial, ekonomi dan lingkungan. Demikian pula, Agenda Lisbon dan Pendidikan dan Pelatihan dalam program kerja 2010 memberikan koheren terhadap Kerangka Pendidikan untuk Pembangunan berkelanjutan. Namun, ada kesenjangan informasi tentang bagaimana konsep pendidikan untuk pembangunan berkelanjutan yang diterjemahkan ke dalam praktek di tingkat

* Penulis adalah Dosen Jurusan PAI Fakultas Tarbiyah dan Keguruan UIN Mataram Email: asyarismart@yahoo.com 
negara anggota. Selain itu, negara-negara anggota bisa mendapatkan keuntungan dari pertukaran cara yang baik dan inovatif dalam mengembangkan pendidikan untuk pembangunan berkelanjutan (DGEC 2008, 3-99).

Tujuan dari penelitian ini adalah untuk mempersiapkan inventarisasi praktek inovatif yang baik dengan tujuan merangsang pertukaran praktik yang baik dan inovatif dalam pendidikan untuk pembangunan berkelanjutan. Studi ini telah ditugaskan pada Komisi Eropa , Ditjen Pendidikan dan Kebudayaan, Satuan Belajar: Kreativitas dan Inovasi. Persediaan menggambarkan bagaimana konsep Pembangunan Berkelanjutan telah diterjemahkan dan diimplementasikan dalam program-program pendidikan dan pelatihan dalam formal, informal dan konteks non-formal

Berbagai pemangku kepentingan telah dihubungi dan diminta untuk menggolkan praktik inovatif yang baik dalam pendidikan untuk pembangunan berkelanjutan di 33 negara Eropa, yaitu 27 negara anggota Uni Eropa, tiga negara EEA (Islandia, Lichtenstein, Norwegia) dan tiga negara kandidat (Kroasia, Macedonia, Turki). Secara total, 212 pemangku kepentingan dihubungi dan diberi kesempatan untuk berkontribusi dalam penelitian ini.

Strategi Eropa untuk Pembangunan Berkelanjutan, yang diadopsi pada tahun 2006, mengakui peran pendidikan dan sistem pelatihan yang penting harus bermain untuk mencapai tujuan pembangunan berkelanjutan. Menurut strategi, pendidikan merupakan prasyarat untuk mempromosikan perubahan perilaku dan memberikan semua warga negara dengan kompetensi kunci yang diperlukan untuk mencapai pembangunan berkelanjutan. Sukses dalam merevisi tren berkelanjutan, untuk sebagian besar, tergantung pada pendidikan berkualitas tinggi untuk pembangunan berkelanjutan (Chair, et.al 2012).

Beberapa praktik lapangan yang dilakukan dalam menjamin keberlangsungan pembangunan berkelanjutan adalah gambaran singkat dari 30 praktik yang dipilih untuk tujuan persediaan atas kerja keras mereka dalam pendidikan untuk pembangunan berkelanjutan (ESD). Penyebaran geografis, tingkat cakupan 
organisasi dan melaksanakan Pemilihan akhir dari kerja keras memiliki cakupan geografis yang luas (Chair, et.al 2012).

Contoh-contoh praktek yang dipilih adalah kepedulian pada tingkat implementasi yang berbeda, mulai dari inisiatif lokal (9), melalui daerah (10) dan tindakan nasional (25), untuk proyekproyek dengan Eropa atau International dengan 10 dimensi, yang melibatkan organisasi payung dan aktor negara-negara yang berbeda (Sallis 1993, 12).

Berbagai organisasi, lembaga, masyarakat, dan badan-badan swasta terlibat dalam pelaksanaan praktek. Sebanyak 10 organisasi internasional, dan 7 organisasi nasional berada di antara organisasi terkemuka melaksanakan. Selain itu, 8 perdana menteri, sebagian besar pendidikan, dan 8 badan-badan regional danUniversitas memberikan kontribusi terhadap pengembangan pendekatan yang digambarkan (Wahyudin 2010).

\section{Pembahasan}

Pendidikan dan pelatihan harus memberikan kontribusi untuk pembangunan berkelanjutan, ketiga aspek tersebut yaitu: perspektif sosial, pendidikan dan pelatihan yang memperkuat kohesi sosial dengan investasi dalam modal manusia perspektif ekonomipendidikan dan pelatihan berkontribusi untuk membangun masyarakat berbasis pengetahuan pada pertumbuhan ekonomi yang berkelanjutan; dan,Lingkungan perspektif-pendidikan dan pelatihan sangat penting untuk perubahan perilaku warga pada isu-isu seperti: konsumsi, transportasi, penggunaan berkelanjutan energi (Suyanto 2012).

Meskipun semua kegiatan pendidikan dan pelatihan memiliki potensi untuk memperkuat pembangunan berkelanjutan, diakui bahwa dalam rangka untuk sepenuhnya menyadari potensi ini, kegiatan pendidikan, terutama difokuskan pada pembangunan berkelanjutan diperlukan. Oleh karena itu, PBB, Komisi Ekonomi untuk Eropa menyusun Pendidikan terpisah pembangunan Berkelanjutan. Strategi pembangunan pada tahun 2005, mengakui bahwa: "Pendidikan untuk Pembangunan Berkelanjutan adalah 
proses seumur hidup dari anak usia dini yang lebih tinggi dan pendidikan orang dewasa yang melampaui pendidikan formal (Undang Nomor 14 Tahun 2005 tentang Guru dan Dosen, n.d., UndangUndang No. 20 tabun 2003 Tentang Sistem Pendidikan Nasional, n.d.).

Sebagai nilai, gaya hidup dan sikap didirikan sejak usia dini, peran pendidikan sangat penting terutama untuk anak-anak. Karena pembelajaran terjadi seperti yang kita peran yang berbeda dalam hidup kita, Pendidikan untuk Pembangunan Berkelanjutan harus dianggap sebagai proses. Ini harus menyerap program pembelajaran pada semua tingkatan, termasuk pendidikan kejuruan, pelatihan untuk pendidik, dan pendidikan berkelanjutan bagi para profesional dan pengambil keputusan.

Bersamaan dengan itu, PBB meluncurkan dekade Pendidikan Berkelanjutan Pembangunan (2005-2014), yang memicu nomor penting dari kegiatan di bidang ini. Sejalan dengan Eropa, tetapi juga dengan internasional, perkembangan beberapa negara memiliki daya tarik program nasional sendiri atau strategi pendidikan untuk pembangunan berkelanjutan. Belanda, misalnya, telah meluncurkan dana penting Program berjudul Belajar untuk Pembangunan Berkelanjutan, sementara Inggris telah mengembangkan Strategi Pengembangan Pendidikan Berkelanjutan untuk Inggris disebut 'Belajar terakhir', diikuti oleh Rencana Tindak Pembangunan Pendidikan Berkelanjutan, yang bertujuan untuk mendorong partisipasi yang lebih luas dalam pembangunan berkelanjutan di semua sektor pendidikan dan keterampilan (Shalin 2012).

Sebagaimana diuraikan dalam pertimbangan di atas dan dikonfirmasi oleh laporan kemajuan Strategi Pembangunan Berkelanjutan Eropa tahun 2007, Agenda Lisbon dan Pendidikan dan Pelatihan program kerja 2010 memberikan kerangka yang koheren untuk pembangunan Pendidikan Berkelanjutan di tingkat Eropa. Pada saat yang sama, negara-negara anggota sedang mengembangkan inisiatif perubahan didaerahnya masingmasing. Namun, menurut laporan kemajuan 2007, tampaknya bahwa koordinasi lebih lanjut dan pertukaran antara negara-negara 
perlu untuk memperkuat dan membuat program pendidikan dan kegiatan untuk pembangunan berkelanjutan lebih efektif.

Dalam kerangka di atas, tujuan penelitian ini adalah untuk melakukan inventarisasi inovasi tepat guna yang harus merangsang pertukaran dan inisiatif lebih lanjut dalam pendidikan untuk pembangunan berkelanjutan. Persediaan ini akan menggambarkan bagaimana konsep Pembangunan Berkelanjutan telah diterjemahkan dan diterapkan dalam sampel pendidikan dan program pelatihan. Temuan penelitian ini juga akan menjadi masukan kemajuan berikutnya dengan melaporkan strategi pembangunan berkelanjutan Uni Eropa DG EAC.

Secara tradisional, pembangunan berkelanjutan secara konseptual dianggap dalam tiga pilar utama: Kelestarian lingkungan, Keberlanjutan ekonomi; dan Keberlanjutan sosial. Keberlanjutan lingkungan didefinisikan sebagai kemampuan lingkungan untuk terus berfungsi dengan baik tanpa batas. Tujuan kelestarian lingkungan adalah untuk meminimalkan degradasi lingkungan dan untuk berhenti dan membalikkan proses yang mengarah kelingkungan degradasi. Strategi Pembangunan Berkelanjutan Uni Eropa (SDS) yang diadopsi pada 20011 dan diperbaharui di 20.062, dan "6 Aksi Lingkungan Program (6 EAP) 3, menetapkan tujuan keseluruhan dan tindakan nyata untuk menghadapi tantangan untuk periode mendatang. Dokumen memberikan latar belakang yang baik untuk mengidentifikasi pilihan isu tematik utama yang sering merujuk pada pilar lingkungan dari pembangunan berkelanjutan. Ini disajikan dalam kotak (Slamet 1999).

Keberlanjutan ekonomi didefinisikan sebagai cara untuk mencapai pertumbuhan ekonomi sementara menghormati batas lingkungan, mencari cara untuk meminimalkan kerusakan alam dan memanfaatkan sumber daya bumi secara berkelanjutan. Dimensi ekonomi pembangunan berkelanjutan dikembangkan oleh Agenda 214, yaitu Program PBB. Agenda 21 menyatakan bahwa: Kebijakan ekonomi masing-masing negara dan hubungan ekonomi 
internasional keduanya memiliki relevansi besar untuk pengembangan berkelanjutan

Konsep lain yang relevan untuk pilar ekonomi "bisnis yang berkelanjutan adalah pembangunan berkelanjutan jika telah disesuaikan praktek terhadap penggunaan sumber daya terbarukan dan bertanggung jawab atas dampak lingkungan dan sosial dari aktivitasnya. Ini termasuk bisnis yang mungkin ingin beroperasi secara bertanggung jawab sosial serta melindungi lingkungan

Gagasan bisnis yang berkelanjutan telah diuraikan oleh Komisi Komunikasi Eropa Melaksanakan kemitraan untuk pertumbuhan dan pekerjaan: membuat Eropa tiang keunggulan pada tanggung jawab sosial perusahaan "dimana Corporate Social Responsibility adalah didefinisikan sebagai: "Sebuah konsep dimana perusahaan mengintegrasikan kepedulian sosial dan lingkungan di mana bisnis mereka beroperasi dan interaksi mereka dengan para pemangku kepentingan mereka pada basis sukarela.

Pilar sosial pembangunan berkelanjutan didefinisikan sebagai kumpulan tindakan dan upaya untuk mempromosikan pembangunan yang tidak menguras stok sosial dan sumber daya manusia melainkan memberikan kontribusi terhadap peningkatan potensinya. Pilar sosial juga mengacu pada konsep "membangun masyarakat yang berkelanjutan dan harmonis". Gagasan keberlanjutan sosial telah dikembangkan pada Agenda Lisbon di Eropa menjadi Strateg Ketenagakerjaan dan inisiatif beberapa Komunitas lain untuk lokal dan pengembangan masyarakat (Suparlan 2006).

Perlu dicatat bahwa batas antara isu tematik yang dipilih di bawah setiap pilar pembangunan berkelanjutan tidak selalu yang jelas. Namun, klasifikasi tersebut memungkinkan untuk kejelasan presentasi, seleksi dan klasifikasi, serta untuk menggambarkan berbagai isu-isu utama yang dipertaruhkan di pembangunan berkelanjutan. Perlu ditekankan bahwa penjabaran konsep kerja dan konseptual Kerangka hanyalah alat yang akan digunakan dalam konteks penelitian ini, dan tidak memiliki klaim untuk 
berkontribusi terhadap pemikiran baru dengan perdebatan teoritis dan akademis pada pembangunan berkelanjutan (Zazin 2011).

Pembelajaran formal: pembelajaran yang terjadi dalam konteks terorganisir dan terstruktur (yaitu lembaga pendidikan formal seperti sekolah, perguruan tinggi, pelatihan kejuruan institut dan universitas), dan mengikuti desain terstruktur tertentu. Ini biasanya mengarah ke pengakuan formal (diploma, sertifikat). Dalam kasus tersebut, isu pembangunan berkelanjutan cenderung dimasukkan dalam kurikulum lembaga (Weiss, et al 2010,1-52).

Pembelajaran non formal merupakan pembelajaran yang tertanam dalam kegiatan yang direncanakan yang tidak secara eksplisit ditunjuk sebagai pembelajaran formal, tetapi yang mengandung elemen belajar penting, seperti keterampilan kejuruan yang diperoleh di tempat kerja. Pembelajaran informal: pembelajaran yang dihasilkan dari aktivitas kehidupan sehari-hari yang berhubungan dengan pekerjaan, rekreasi, bebas waktu, dll Jenis pembelajaran kadang-kadang disebut sebagai pengalaman belajar. Umumnya, tidak mengarah ke sertifikasi

Pilar pembangunan berkelanjutan tertutup. Studi ini telah diuraikan kerangka analisis mengidentifikasi dimensi utama dari masing-masing tiga pilar pembangunan berkelanjutan yang akan digunakan ketika menggambarkan dan mengklasifikasikan praktek. Tujuannya adalah untuk memahami pilar pembangunan berkelanjutan yang proyek atau program yang bertujuan untuk mengatasi dan untuk menangkap berbagai isu tematik di bawah masing-masing pilar

Sebanyak 11 praktek difokuskan pada siswa antara usia 12 dan 18, lima di antaranya proses belajar mengadopsi formal, dua kombinasi formal dan informal dan hanya satu dilaksanakan sebagai jenis belajar informal. Hal ini mencerminkan fakta bahwa kebanyakan praktek pembangunan berkelanjutan diperkenalkan dalam kurikulum sekolah, yang memudahkan akses ke siswa muda dan menyajikan kemungkinan untuk mencapai keluarga siswa tidak langsung. 
Tiga praktek difokuskan pada siswa dan orang dewasa antara usia 18 dan 30, dengan pendekatan berkonsentrasi pada pengarusutamaan pembangunan berkelanjutan ke perguruan tinggi (baik melalui kurikulum atau dengan bertindak sebagai lembaga yang berkelanjutan itu sendiri). Dalam beberapa kasus, contoh inovatif yang berfokus pada karyawan, tanpa target usia. Secara keseluruhan, sebagian besar praktik yang dipilih diterapkan dalam konteks sekolah dan universitas menargetkan siswa dan mahasiswa dari usia 12 sampai 30. (Undang-Undang No. 20 tabun 2003 Tentang Sistem Pendidikan Nasional, n.d.)

Pilar pembangunan berkelanjutan tertutup pada Praktek yang dipilih yang memberikan penyebaran baik kegiatan yang berfokus pada ketiga pilar pembangunan berkelanjutan: lingkungan, ekonomi dan sosial. Penting untuk dicatat bahwa fokus tematik tidak saling eksklusif dan karena itu salah satu praktek inovatif bisa menutupi beberapa tema

Demikian pula, integrasi masalah lingkungan pada proses pengambilan keputusan bisnis tampaknya sedikit membahas masalah di bawah pilar ekonomi. Perlu disebutkan, bagaimanapun, bahwa ini juga dapat terkait dengan jumlah yang lebih kecil dari praktek pengarusutamaan ESD di tingkat perusahaan. Akhirnya, demografi dan flexicurity memiliki keduanya telah dimasukkan ke dalam pendidikan di empat praktek di bawah pilar sosial. Singkatnya, konsumsi berkelanjutan menjadi fokus tematik paling populer, yang dimasukkan ke dalam pendidikan sebesar 23 praktek, sementara pengurangan emisi gas adalah yang membahas masalah, yang diarus utamakan ke dalam pendidikan.

\section{Catatan Akhir}

Elemen-elemen inovatif diantaranya adalah Inovasi dalam konten: Meskipun pembangunan berkelanjutan secara eksplisit dimasukkan dalam sekolah kurikulum, kekuatan dari program ini adalah untuk memastikan bahwa prinsip pembangunan berkelanjutan dan masalah yang terinternalisasi dalam gaya hidup 
siswa. Inovasi dalam metode penyampaian: dorongan siswa untuk memberikan kontribusi terhadap mereka.

Kebijakan Lingkungan Hidup sekolah telah menghasilkan perubahan yang signifikan dalam cara siswa belajar dan mereka lebih mungkin untuk meningkatkan pembelajaran dan telah menjadi lebih terbuka terhadap lainnya bentuk pembelajaran. Inovasi pada tingkat kelembagaan membantu pemerintah pendidikan secara formal mengakui kebutuhan untuk mengatasi isu-isu pembangunan berkelanjutan di pendidikan formal. Jika saat ini sudut pandang dipertahankan, ada kemungkinan bahwa Pendidikan untuk Pembangunan Berkelanjutan akan resmi termasuk dalam kurikulum nasional.

Inovasi dalam menempa kemitraan baru dan jaringan: Sekolah bekerja sama dengan perusahaan lokal dan kelompok masyarakat untuk melaksanakan kegiatan mereka.

Kunci sukses Perubahan yang signifikan dalam sikap siswa terhadap pembangunan berkelanjutan telah diamati sebagai hasil dari inisiatif. Selain itu, sekolah tampaknya memiliki partisipasi siswa terintegrasi dalam pengambilan keputusan kedepan mengenai perkembangan sekolah, dan dewan lokal telah secara bertahap mengembangkan sikap yang lebih positif terhadap agenda pembangunan berkelanjutan.

\section{Daftar Pustaka}

Chair, et.al, Stephen M. Quintana. 2012. "Ethnic and Racial Disparities in Education: Psychology's Contributions to Understanding and Reducing Disparities." A Report by the American Psychological Association Presidential Task Force on Educational Disparities. American Psychological Association. https://www.apa.org/ed/resources/racialdisparities.pdf.

DGEC. 2008. DGEC, Inventory Of Innovative Practices In Education For Sustainable Development. Danish Technology Institute.

Sallis, Edward. 1993. Edward Sallis, Total Quality Management in Education. London: Kogam Page. 
Shalin, D.N. 2012. Highschool Graduation and Dropout Rates in Nevada. Las Vegas, NV, USA: Tyler.

Slamet, Margono. 1999. Filosofi Mutu dan Penerapan Prinsip-Prinsip Manajemen Mutu Terpadu. Bogor: IPB Bogor.

Suparlan. 2006. Guru sebagai Profesi. Yogyakarta: Hikayat.

Suyanto, B. 2012. "PenyusunanKebijakandan Program Untuk

Mengeliminasi Angka Putus Sekolah dan Siswa Rawan Drop Out di Provinsi JawaTimur." In Proceeding. Tangerang: The Aryaduta Lippo Village.

Undang Nomor 14 Tabun 2005 tentang Guru dan Dosen. n.d.

Undang-Undang No. 20 tahun 2003 Tentang Sistem Pendidikan Nasional. n.d.

Wahyudin, D. 2010. "Model Pembelajaran Icare Pada Kurikulum Mata Pelajaran TIK di SMP." Jurnal Penelitian Pendidikan 11 (1).

Weiss, et al, H. B. 2010. "Reframing Family Involvement in Education: Supporting Families to Support Educational Equity." Research Review 5 (April): 1-52.

Zazin, N. 2011. Gerakan Menata Mutu Pendidikan. Yogyakarta: ArRuzz Media. 